
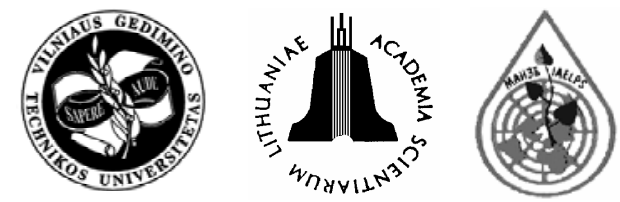

\title{
PHYTOREMEDIATION FOR HEAVY METAL-CONTAMINATED SOILS COMBINED WITH BIOENERGY PRODUCTION
}

\author{
Luc Van Ginneken ${ }^{1}$, Erik Meers ${ }^{2}$, Ruben Guisson ${ }^{3}$, Ann Ruttens ${ }^{4}$, Kathy Elst ${ }^{5}$, \\ Filip M. G. Tack ${ }^{6}$, Jaco Vangronsveld ${ }^{7}$, Ludo Diels ${ }^{8}$, Winnie Dejonghe ${ }^{9}$ \\ 1, 3, 5, 8, 9 Environmental and Process Technology, Flemisch Institute for Technological Research, \\ Boeretang 200, 2400 Mol, Belgium.E-mail: ${ }^{1}$ luc.vanginneken@vito.be; ${ }^{3}$ ruben.guisson@vito.be; \\ ${ }^{5}$ kathy.elst@vito.be; ${ }^{8} 1$ udo.diels@vito.be; ${ }^{9}$ winnie.dejonghe@vito.be \\ ${ }^{2,6}$ Laboratory of Analytical Chemistry and Ecochemistry, Ghent University, Coupure Links 653, \\ 9000 Gent, Belgium.E-mail: ${ }^{2}$ Erik.Meers@UGent.be, ${ }^{6}$ Filip.Tack@UGent.be \\ ${ }^{4,7}$ Centre for Environmental Sciences, Department of Environmental Biology, University of Hasselt, \\ Diepenbeek Campus, Agoralaan, Building D, 3590 Diepenbeek, Belgium \\ E-mail: ${ }^{4}$ ann.ruttens@uhasselt.be; 7 jaco.vangronsveld@uhasselt.be
}

Submitted 15 May 2007; accepted 24 Sept. 2007

\begin{abstract}
In June 2007, a project started in Flanders (Belgium) in which we will apply phytoremediation to clean soils that are diffusely polluted with heavy metals. Uptake ranges of heavy metals by rape seed, maize and wheat will be enhanced by increasing the bioavailability of these heavy metals by the addition of biodegradable physico-chemical agents and by stimulating the heavy-metal uptake capacity of the microbial community in and around the plant. In addition, the harvested biomass crops will be converted into bioenergy by using different energy-recovery-techniques. The energy and heavy metal mass balances will be compared for four different energy-recovery techniques (anaerobic digestion, incineration, gasification and production of biodiesel). The overall information obtained will result in an economic evaluation of the use of phytoremediation combined with bioenergy production for the remediation of sites which are diffusely polluted with heavy metals. In the present review we will first explain the most important research steps investigated in our phytoremediation project. Secondly, an overview of literature discussing the phytoremediation capacity of rape seed to clean soils that are contaminated with heavy metals and the possibilities to produce biodiesel from this (heavy metal polluted) rape seed will be discussed in more detail.
\end{abstract}

Keywords: phytoremediation, heavy metals, biomass, energy recovery, rape seed, biodiesel.

\section{Introduction}

In Flanders (Belgium, Europe) large-surface areas are diffusely polluted with inorganic pollutants like heavy metals. The currently applied remediation techniques (dig $\&$ dump of soil and pump \& treat of groundwater) are too expensive and not sustainable for these large areas. For almost two decades now, the use of phytoremediation (i.e. uptake and concentration of contaminants from the environment in plant biomass) is also proposed as an alternative technique to remediate soils contaminated with trace elements. Phytoremediation is a low-cost option, particularly suited to large sites that have relatively low levels of contamination. Therefore, a Flemish project (which will start in June 2007) was designed to evaluate the feasibility of applying phytoremediation to remove heavy metals from contaminated soils and groundwater, and to evaluate the feasibility of converting the harvested biomass into bioenergy. The aim of this review is twofold: 1) to briefly present the most important research steps of our phytoremediation project, and 2) to give an overview of literature discussing the phytoremediation capacity of rape seed to clean soils that are contaminated with heavy metals, as well as the possibilities to produce biodiesel from this (heavy-metal polluted) rape seed.

\section{Project description}

Our phytoremediation research project consists of three main research topics, which will be briefly discussed in the next sections.

\subsection{Study of energy crop production in combination with phytoremediation}

First, synergism possibilities between energy crop production and phytoremediation to remove heavy metals from the soil and groundwater in the long term will be investigated.

The increase of the uptake of heavy metals by the energy crops can be influenced by:

- increasing the bioavailability of heavy metals by the addition of biodegradable physicochemical factors, such as chelating agents, micronutrients, etc. 
- stimulating the heavy-metal uptake capacity of the microbial community in and around the plant.

This faster uptake of heavy metals will result in shorter and therefore less expensive remediation periods. However, with the use of synthetic chelating agents, the risk of increased leaching must be taken into account.

\subsection{Study of energy crop valorization}

Next, the valorization of the bioenergy crops by different energy-recovery-techniques (incineration, gasification, anaerobic digestion and pure plant oil production) will be studied (Fig 1).

The energy balances and heavy metal mass balances will be compared for the four studied energy-recoverytechniques. As the valorization of contaminated biomass might have effects on the process of these techniques (flue gasses, slag, microbial organisms), recommendations will be made in order to adjust certain process parameters as well.

\subsection{Economic study}

The overall information obtained will finally result in an economic evaluation of the use of phytoremediation combined with energy crop production for the remediation of sites diffusely polluted with heavy metals. This is necessary because the feasibility of the long-term strategy of phytoremediation has to be tested against the current remediation techniques.

Several energy crops will be applied, including rape seed, maize, wheat, and short rotation coppice (Fig 2). The phytoextraction potential of the species, the fate of heavy metals in the plants, and the potential of these crops for the sustainable management of these contaminated soils and the production of bioenergy will be explored.

3. Potential of phytoremediation with rape seed together with the production of biodiesel for the remediation of soils polluted with heavy metals in Europe: an overview

\subsection{Estimation of the area polluted with heavy metals in Europe}

Among the many heavy metals released from various products and processes, cadmium, lead and mercury are of great concern to human health because of their toxicity and their potential to cause harmful effects at low concentrations and to bioaccumulate.

Studies in the Kempen region in Belgium and the Netherlands stipulated that in some cases the standards for heavy metal content in green vegetables in soils with a low $\mathrm{pH}$ were exceeded [1]. The production of energy crops as phytoremediator seems feasible in these cases.

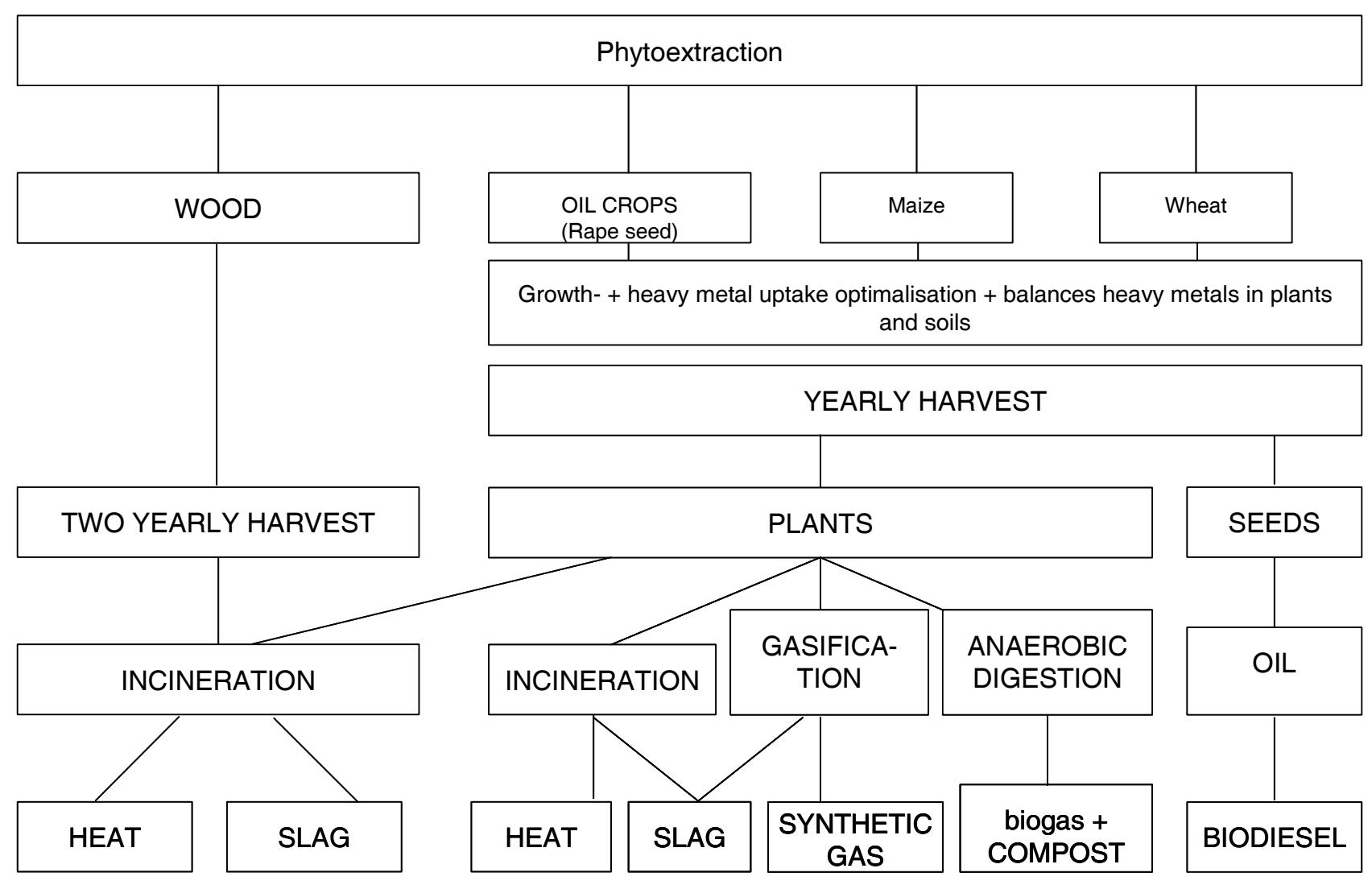

Fig 1. Representation of studied techniques to produce bioenergy from energy crops used in the remediation of soils contaminated with heavy metals 

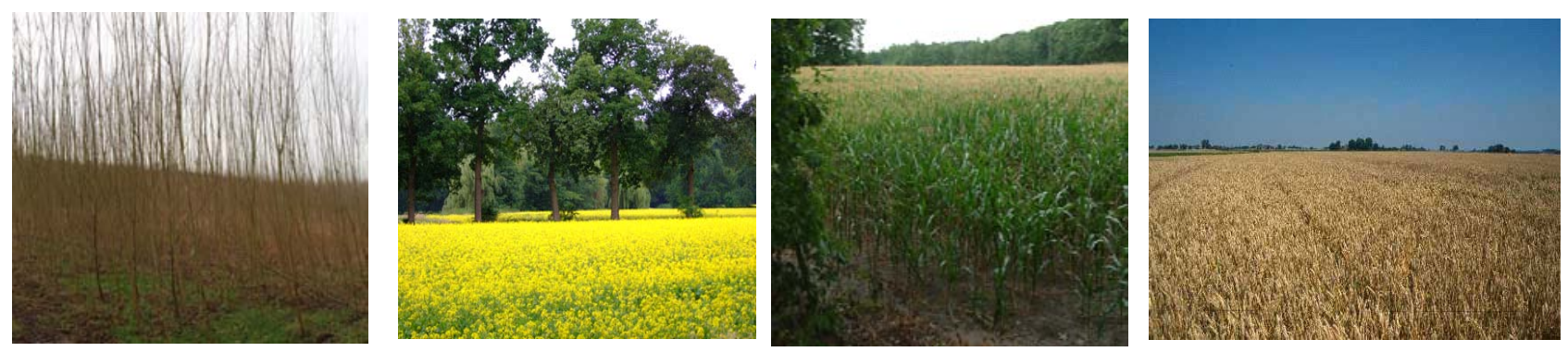

Fig 2. The uptake of heavy metals, the winning of bioenergy and the use of plants to remediate soils polluted with heavy metals will be optimized and evaluated economically for short rotation coppice, rape seed, maize and wheat

A survey of the European Environment Agency says that although there may not be severe widespread soil contamination with heavy metals in Europe, there are many localized areas where intense heavy-metal contamination is known to exist (hot spots) [2].

Fig 3 shows the location of zones with high probability of soil contamination through heavy industry (pink spots). The EEA report [2] repeatedly notes the lack of available and coherent scientific data on soil heavy-metal contamination: 'there is no harmonized monitoring of local soil contamination in Europe and many countries do not yet have national inventories'. Hence the map was made by using the location of areas of heavy industry as a proxy data set.

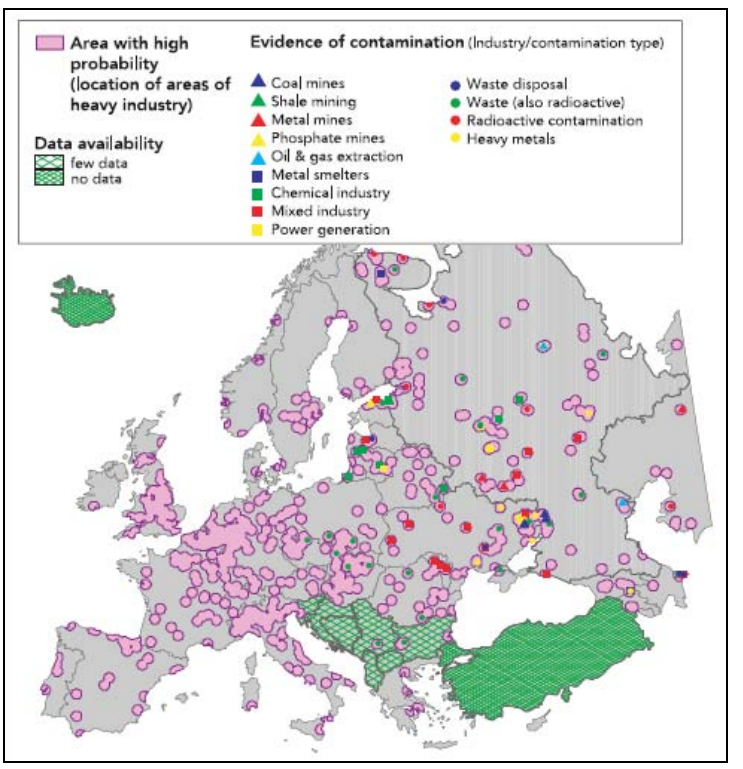

Fig 3. Probable problem areas of local contamination in Europe [2]

Nevertheless, Fig 3 gives a good indication of the extent of soil contamination due to heavy industries, which are likely to be related to heavy-metal contaminations. The areas where the probability of occurrence of local contamination is high are located in North-West Europe, from Nord-Pas de Calais in France to the RheinRuhr region in Germany, across Belgium and the Netherlands. Other areas include the Saar region in Germany; northern Italy, north of the river Po, from Milan to Padua; the region located at the corner of Poland, the Czech Re- public and the Slovak Republic, with Krakow and Katowice at its centre (the so-called Black Triangle); and the areas around all major urban agglomerations in Europe. At least the conclusion can be made that hot spot soil contamination by heavy industries is not a marginal phenomenum [2].

According to official emission data, total anthropogenic emissions of lead in European countries in 2004 were 5580 tonnes. In the most pollution-loaded areas of such countries as Belgium, Germany, Portugal, Poland, Greece, etc. (Fig 4), deposition fluxes often exceed 2 $\mathrm{kg} / \mathrm{km}^{2} / \mathrm{y}[3]$.

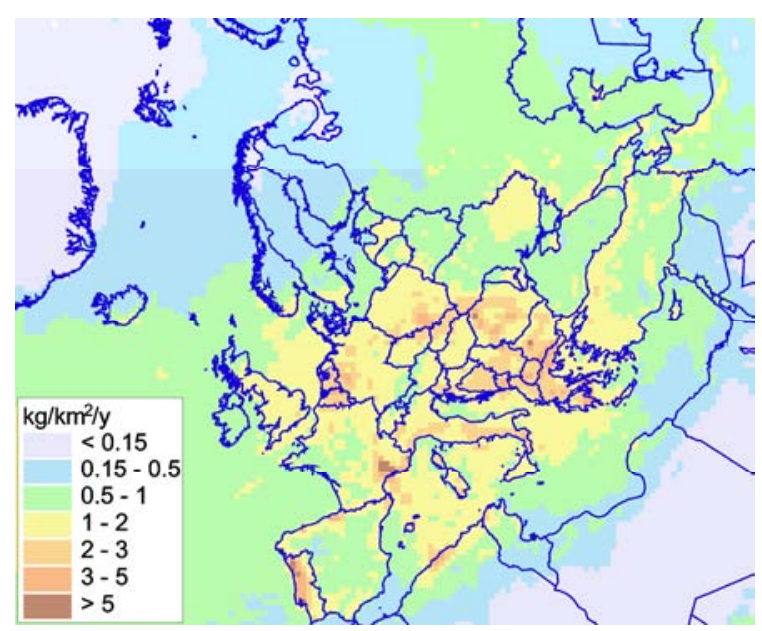

Fig 4. Spatial distribution of lead depositions in Europe in 2004 [3]

The total deposition of cadmium from anthropogenic sources to European countries in 2004 is estimated at 181 tonne. The highest anthropogenic depositions (Fig 5) were obtained for the FYR of Macedonia, followed by Slovakia, Bulgaria and Poland [3].

\subsection{Potential of rape seed for removal of heavy metals from the soil}

Phytoremediation is regarded as a non-intrusive, inexpensive approach for remediating environmental media, and is being pursued as a new approach for the cleanup of contaminated soils, water and ambient air [4]. Phytoremediation in general implies the use of plants (in combination with their associated micro-organisms) to remove, degrade or stabilize contaminants [5]. One pos- 
sible phytoremediation option is the phytoextraction of contaminants. Phytoextraction is based on the accumulation of contaminants in harvestable plant tissues [6] and their subsequent removal by harvesting the plants. It is mostly described in literature for metals ( $\mathrm{Ag}, \mathrm{Cr}, \mathrm{Co}, \mathrm{Cd}$, $\mathrm{Cu}, \mathrm{Hg}, \mathrm{Mn}, \mathrm{Mo}, \mathrm{Ni}, \mathrm{Pb}, \mathrm{Ni}, \mathrm{Zn}$ ), metalloids (As, Se), radionuclides ( $\mathrm{Sr}, \mathrm{Cs}, \mathrm{Pu}, \mathrm{U})$ and non-metals (B). Metal phytoextraction research and applications can be subdivided in two directions: on the one hand, the use of natural hyperaccumulators, such as Alyssum bertolonii or Thlaspi caerulescens, and, on the other hand, the use of high biomass agronomic crops in which (increased) accumulation may be induced by the use of metalmobilizing soil amendments.

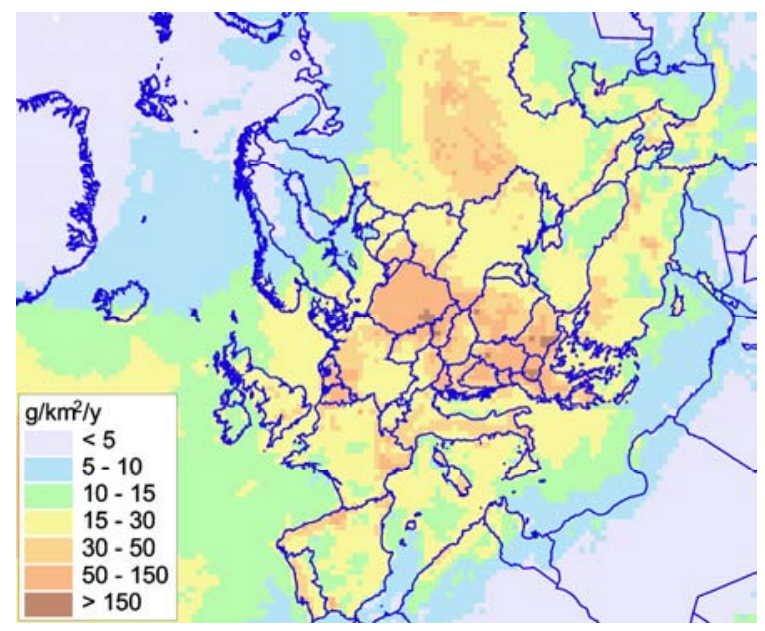

Fig 5. Spatial distribution of cadmium depositions in Europe in 2004 [3]

Because of the long required remediation times of phytoextraction, necessary for the removal of heavy metals from moderately contaminated soils (years to decades), Meers [7] argued that phytoextraction could only be considered feasible when the biomass produced during the phytoremediation process could be economically valorised. The authors stated that the use of metalaccumulating bioenergy crops might be suitable for this purpose.

One of the directions in which our research is currently evolving, is the use of oil-producing plant species, such as rape seed (Brassica napus) for phytoextraction purposes, or more in general for the sustainable use of metal-contaminated land. Several plants of the family of the Brassicaceae are capable of accumulating high metal concentrations in their above-ground plant parts. Extreme examples are the metal hyperaccumulators mentioned above [8, 9]. Thlaspi caerulescens, for example, has long been known to be capable of accumulating $\mathrm{Zn}$ concentrations in its foliar dry matter in excess of 10000 mg. $\mathrm{kg}^{-1}$ [10]. Robinson et al. [11] reported that $T$. caerulescens, at a biomass yield of $2.6 \mathrm{t}^{-\mathrm{ha}^{-1}}$ and a dry weight concentration of $1.16 \%$ for $\mathrm{Zn}$ and $0.16 \%$ for Cd could annually remove $60 \mathrm{~kg}$ of $\mathrm{Zn}$ and $8.4 \mathrm{~kg}$ of $\mathrm{Cd}$ per ha. A major drawback of hyperaccumulating plant species in the context of phytoextraction, is that they are generally slow growers with a low biomass production. This impairs their phytoextraction applications, since the metal removal efficiency is determined by the harvestable plant biomass multiplied by the concentration of heavy metals contained within this biomass. Another drawback is the fact that extreme concentrations in the soil may be a prerequisite for vigorous plant growth and the ability to compete with other faster growing, non-accumulating plant species. Moreover, agronomic practices for most of these species are not well established (e.g. pest and weed control). Also, the fact that hyperaccumulation is often metal-selective (only 1 or 2 metals), and possible diffusion limitations at the soil level reduce the overall suitability of hyperaccumulators for phytoextraction purposes.

However, within the Brassica genus, there also exist some other species which show the tendency to accumulate high metal concentrations, and which can be characterized as metal accumulators. Some of these species grow fast and produce a high biomass. Examples are Brassica juncea (Indian mustard), Brassica rapa (field mustard) en Brassica napus (rape) [12]. Brassica juncea was shown to accumulate high levels of heavy metals including $\mathrm{Cd}, \mathrm{Cr}, \mathrm{Cu}, \mathrm{Ni}, \mathrm{Pb}$ and $\mathrm{Zn}$ under certain conditions which particularly enhance the solubility of metals in the soil [13-16]. Do Nascimento et al. [17] argued that metal accumulation in Brassica juncea could be achieved just as efficiently with degradable low-molecular-weightorganic-acids than by synthetic chelators. Meers et al. [18] found that of four agronomic species tested, Brassica rapa exhibited the highest affinitity for accumulating $\mathrm{Cd}$ and $\mathrm{Pb}$ from the soil, either with or without additional use of mobilizing soil amendments. However, accumulation was too low to consider phytoremediation as the sole objective. Marchiol et al. [19] found that two Brassica species (Brassica napus and Raphanus sativus) were moderately tolerant when grown on a multi-metalcontaminated soil. They concluded that this species could possibly be used with success in marginally polluted soils where their growth would not be impaired, and the extraction of heavy metals could be maintained at satisfying levels. In contrast with hyperaccumulators, Brassica napus is one of the oldest cultivated oil crops. In field experiments conducted at two different metalcontaminated sites in Belgium and the Netherlands, Cd concentrations in 18 different rape seed accessions ranged between 3.6 to $8.1 \mathrm{mg} / \mathrm{kg} \mathrm{DW}$ at a total soil Cd concentration of $5.5 \mathrm{mg} \mathrm{Cd} / \mathrm{kg}$ soil DW for the Belgian site, and between 5.2 and $11.3 \mathrm{mg} / \mathrm{kg} \mathrm{DW}$ at a total soil Cd concentration of $2.5 \mathrm{mg} \mathrm{Cd} / \mathrm{kg}$ soil DW for the Dutch site [20]. Ebbs and Kochian [12] reported Cd concentrations in B. napus shoots of $3 \mathrm{mg} / \mathrm{kg} \mathrm{DW}$ after a growing period of 3 weeks in a neutral silty soil with total Cd concentrations of $40 \mathrm{mg} / \mathrm{kg}$. Zinc concentrations in the same plants were about $600 \mathrm{mg} / \mathrm{kg}$ DW. No adverse effects on plant growth were observed at these concentrations. 


\subsection{Production of biodiesel fuel from rape seed oil by transesterification}

After harvesting rape seed from a contaminated site, the seeds may be further processed to obtain the rape seed oil. The main processing steps include: i) cleaning the seeds, ii) preconditioning the seeds by heating, iii) flaking the preheated seeds, iv) cooking the flakes, v) separating the oil and cake by pressing the flakes, vi) extracting the oil remaining in the cake with hexane, and finally vii) refining the crude rape seed oil. Refining of crude vegetable oil is carried out to remove unwanted minor components to produce a stable oil. The process involves the removal of phospholipids and free fatty acids in the degumming and neutralization steps. The oil is then bleached to remove color pigments, and deodorized to remove odoriferous compounds by distillation at high temperature under vacuum. As such, a refined vegetable oil can be obtained.

Low-molecular-weight organic liquids can be produced from (refined) vegetable oil (such as rape seed oil) and can be used or are proposed as fuel for vehicles. The concept of using vegetable oil as a fuel is as old as the combustion engine itself. Rudolf Diesel developed the diesel engine with the full intention of running it on a variety of fuels - including vegetable oil - and even used peanut oil as a fuel to demonstrate his engine at the Paris World Exhibition in 1900 [21, 22].

There are several ways of using vegetable oils - either virgin or waste - as an alternative fuel. These include: i) direct use and blending with diesel fuel, creation of microemulsions with alcohols, and ii) thermal cracking (pyrolysis) [23]. There are, however, known problems related to these primary options to produce biofuels from vegetable oils [23]. The high viscosity, acid composition, free fatty acid content, and gum formation make it impractical and not very favourable for using straight vegetable oils and/or their blends in diesel engines. A lower cetane number, lower energy content and carbon deposits on the injector tips were reported when using microemulsions of vegetable oils with alcohols. Pyrolysed vegetable oils have in general acceptable levels of sulphur, water and particulate matter, but otherwise may have unacceptable levels of ashes and carbon residues [24].

The most promising way of using vegetable (rape seed) oils as an alternative fuel, however, is believed to be transesterification [23, 25]. Transesterification is the general term used to describe the reaction in which an ester is transformed into another ester through interchange of the alkoxy moiety [25]. In the transesterification of vegetable oils (generally rape seed oil), the triglycerides (present in the oil) react with a simple alcohol (generally methanol) to produce esters (generally fatty acid methyl esters, FAMEs) and glycerol. These (methyl) esters - commonly known as biodiesel - are very similar to conventional diesel fuel, and can be used in any conventional diesel engine without any modification. Crude glycerol, obtained as a by-product from biodiesel production, can be used as a raw material, e.g. in the food, pharmaceutical and cosmetical industry.

The overall transesterification process is normally a sequence of three consecutive, reversible reaction steps $[26,27]$. In the first reaction step (Fig 6), a triglyceride is reacted with alcohol to form a diglyceride, then from diglyceride a monoglyceride is obtained, and finally from monoglyceride glycerol is obtained [27].

Although the stoichiometric (molar) ratio of alcohol to triglyceride is $3: 1$, an excess of alcohol is used to drive the equilibrium to a maximum ester yield [22, 23, 25]. An excessive amount of alcohol, however, makes the recovery of the glycerol difficult and laborious, so the ideal alcohol/triglyceride ratio has to be established empirically [25]. The transesterification reaction also requires a catalyst to improve reaction kinetics under mild reaction conditions [23]. This is usually an alkali or an acid. The use of an enzyme biocatalyst (such as lipase) has also been under investigation in more recent years [28], but the reaction yields as well as the reaction kinetics are still unfavorable compared to the base-catalyzed reaction systems [25]. Important variables in the transesterification process include reaction temperature, molar ratio of alcohol to triglyceride, type and amount of catalyst used, and the vegetable oil feedstock quality (particularly moisture and free fatty acid content) [27].

\subsubsection{Alkali- and acid-catalyzed transesterification}

The base-catalyzed or acid-catalyzed transesterification of the triglycerides in vegetable oil with a simple alcohol, such as methanol and ethanol, to form glycerol and the corresponding fatty acid alkyl esters (i.e. biodiesel) has been the preferred method for biodiesel production for a long time [29]. The alkali catalysts include $\mathrm{NaOH}, \mathrm{KOH}$, and corresponding sodium and potassium alkoxides, such as sodium methoxide and sodium ethoxide $[23,27]$. The acid catalysts include sulfuric, sulfonic and hydrochloric acid [23, 27]. Alkali-catalyzed transesterification is much faster than acid-catalyed transesterification [26], and is therefore most often used in commercial biodiesel production. However, a relatively long reaction time $(1-8 \mathrm{~h})$ is still needed even when using a basic catalyst to form the esters [30].

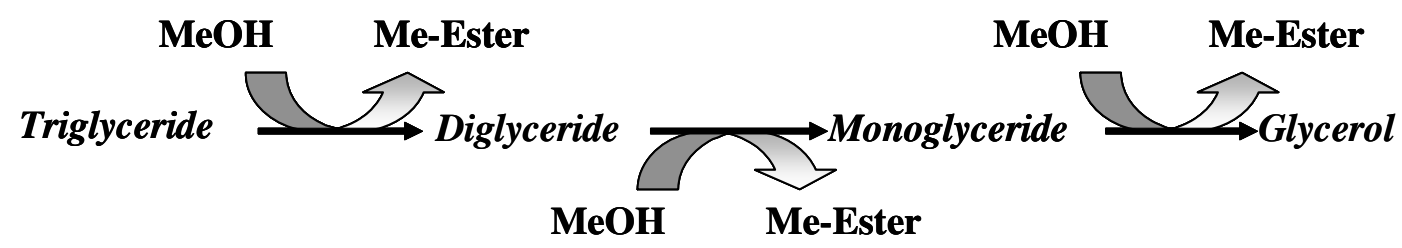

Fig 6. The overall transesterification process of a vegetable oil 
Crude rape seed oil, obtained by pressing oil from rape seeds, usually contains free fatty acids (FFAs), phospholipids, sterols, water, odorants and other impurities [22]. Even refined rape seed oil contains some small amounts of FFAs and water. These FFAs and water contents have significant effects on the transesterification of glycerides with alcohols [23]. For alkali-catalyzed transesterification, the triglycerides and alcohol must be substantially anhydrous because water causes a partial reaction change to saponification, which produces soap $[22,23]$. This soap consumes the catalyst and reduces the catalytic efficiency, as well as causing an increase in viscosity and difficulty in achieving separation of glycerol [31]. Also FFAs are known to react with the alkaline catalyst in the conventional process and form saponified products during the transesterification reactions for biodieselfuel production. This makes downstream processing (i.e. removal and separation of both the catalyst and the saponified products from the glycerol and fatty acid methyl esters) quite complex and renders the production of biodiesel quite costly. Although reaction rates are slow, the use of an acid catalyst (such as sulfuric acid) has been found to be useful for pretreating high free fatty acid feedstocks to convert the FFAs to esters [22, 32]. This can be followed by a standard alkali-catalyzed transesterification to convert the triglycerides to alkyl esters [32].

To overcome these problems associated with the conventional, acid-catalyzed or base-catalyzed process, different authors recently suggested to use supercritical alcohols without the use of a catalyst as an alternative reaction medium. Since non-catalytic transesterification in supercritical alcohols seems to offer notable advantages over the conventional processes (Table 1), this topic will be discussed in the next section.

\subsubsection{Transesterification in supercritical alcohols}

Saka and Kusdiana [30] published the first fundamental study on biodiesel fuel production from rape seed oil in supercritical methanol. In their set-up, rape seed oil was contacted with methanol in its supercritical state for a very short period of time in the absence of a catalyst. A pure component is considered to be in its supercritical state if its temperature and pressure are higher than the critical values (Fig 7), which, for pure methanol, are equal to $\mathrm{Tc}=239.5^{\circ} \mathrm{C}$ and $\mathrm{pc}=80.8$ bar. In another study, Kusdiana and Saka [33] reported on the kinetics of transesterification of rape seed oil to biodiesel fuel in both subcritical and supercritical methanol under different reaction conditions of temperature and reaction time without using any catalyst. Runs were made in a batchtype reaction vessel with temperatures ranging from $200{ }^{\circ} \mathrm{C}$ (subcritical in temperature) to $500{ }^{\circ} \mathrm{C}$ (supercritical state) and with different molar ratios of methanol to rape seed oil $(3.5: 1$ to $42: 1)$. The conversion rate of rape seed oil to its methyl esters was found to increase dramatically in the supercritical state. Since supercritical methanol has a hydrophobic nature and a lower dielectric constant, non-polar triglycerides can be well solvated by supercritical methanol to form a single phase oil/metha- nol mixture. This phenomenon is likely to promote the transesterification reaction of rape seed oil. The overall reaction was found to proceed as a first order reaction as a function of the concentration of triglycerides and reaction temperature. Similar results were also obtained by Weyten et al. [34, 35], who studied the kinetics of soybean oil transesterification in supercritical methanol in both batch and continuous mode, and by Madras et al. [36], who studied the kinetics of sunflower oil transesterification in supercritical methanol and ethanol in a batch system. Kusdiana and Saka [37] also reported on the methyl esterification of FFAs of rape seed oil in supercritical methanol. This study was undertaken because FFAs (which are present in commercially available crude oils and fats) are known to react with the alkaline catalyst in the conventional process and form saponified products during the transesterification reactions for biodiesel fuel production. Their results showed that FFAs of rape seed oil could be methyl esterified in supercritical methanol. Methyl esterification of saturated fatty acids proceeded better at temperatures above $400{ }^{\circ} \mathrm{C}$ in supercritical methanol, while for the unsaturated fatty acids, a lower temperature of $350{ }^{\circ} \mathrm{C}$ was more appropriate. Since a total yield of $95 \%$ of methyl esters could be obtained by methyl esterification of FFAs at $350{ }^{\circ} \mathrm{C}$ (which is similar to the conversion obtained by transesterification of rape seed oil at the same temperature), the authors concluded that the best condition for both reactions (i.e. methyl esterification of FFAs and transesterification of triglycerides), which take place simultaneously, is at a temperature of $350{ }^{\circ} \mathrm{C}$. In addition, Warabi et al. [38] showed that transesterification of triglycerides (rape seed oil) was slower in reaction rate than alkyl esterification of fatty acids for different alcohols employed, proving that FFAs present in vegetable oil would be completely converted to alkyl esters under the treatment of transesterification in the supercritical alcohol treatment. Furthermore, it was observed that (commercially-available) saturated fatty acids, such as palmitic and stearic acids, had slightly lower reactivity than those of unsaturated fatty acids, such as oleic, linoleic and linolenic.

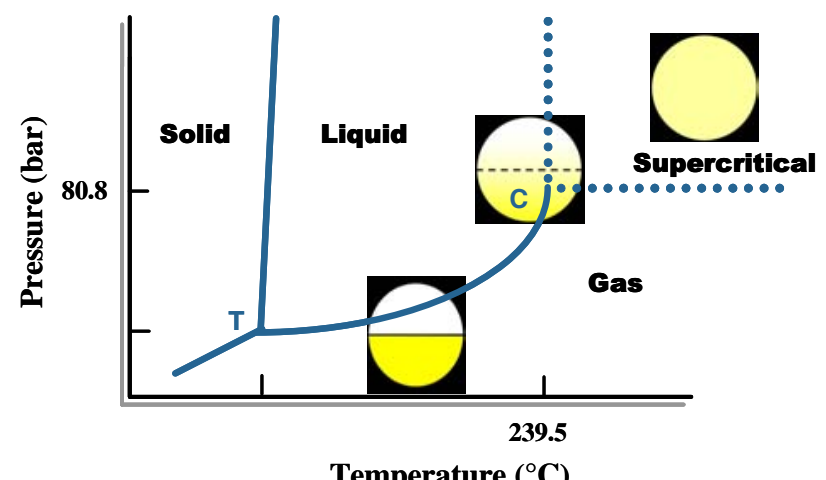

Fig 7. The phase diagram of methanol. The critical point $\left(T_{c}=239.5^{\circ} \mathrm{C}, p_{c}=80.8\right.$ bar $)$ is indicated as " $\mathrm{C}$ "

For alkali-catalyzed transesterification, the triglycerides and alcohol must be substiantially anhydrous because water causes a partial reaction change to saponifi- 
cation, which produces soap. This soap consumes the catalyst and reduces the catalytic efficiency, as well as causing an increase in viscosity and difficulty in achieving separation of glycerol [31]. Therefore, Kusdiana and Saka [39] studied the effect of water on the yield of methyl esters in transesterification of triglycerides and methyl esterification of fatty acids as treated by the supercritical methanol method $\left(350{ }^{\circ} \mathrm{C}, 43 \mathrm{MPa}, 4 \mathrm{~min}\right.$. of treatment with a methanol to oil molar ratio of 42:1). For the transesterification of triglycerides in supercritical methanol, the amount of water added into the reaction system did not have a significant effect on the conversion. A complete conversion was still obtained, even for a water content of up to $36 \%$. For the methyl esterification of oleic acid, the conversion to methyl oleate was somewhat reduced when the water content was increased, which was probably attributed to further hydrolysis of the formed methyl oleate to oleic acid at high temperature. In addition, further experiments were carried out by adding a greater amount of water to the reaction system. A water addition as high as $50 \%$ did not greatly affect the yield of methyl esters. In the presence of water, triglycerides in vegetable oil were probably hydrolyzed to fatty acids during supercritical treatment, which could then be further methyl esterified during the supercritical methanol treatment to produce a high yield. These results indicated that the presence of water in crude vegetable oil as well as in their wastes is not an obstacle in the supercritical process, and hence various types of vegetable oils from virgin to crude and their wastes can be readily used for biodiesel production by the supercritical methanol method.

\subsection{European and Member State policies on support- ing biofuels}

Gaining biodiesel from oily biomass, produced during the phytoremediation process, could be an interesting economic valorisation. However, once biodiesel has been produced, it must be brought to the market. Biofuels are suffering from a higher production cost in comparison with its fossil counterpart. EU- produced biodiesel would break even at oil prices of $60 €$ per barrel [40]. At the end of April 2007, a barrel of oil was priced 49.78 $€$ [41]. Biofuels therefore need some support to trigger a market breakthrough. The European Commission (EC) and its Member States are using both legislation and formal directives to promote biofuel production and use within the EU, such as:

\subsubsection{Support to agriculture}

Under the CAP (common agricultural policy), applied in the first 15 countries of the EU since 1993, EU farmers are required to set aside $10 \%$ of their land. In return they receive a set-aside compensation payment. Additionally EU farmers are allowed to plant oilseeds on the set-aside land [42].

Special aid for energy crops grown on non-set-aside land was initiated in 2004. Energy crops - those grown for the production of biofuels or for use as biomass in the production of electric and thermal energy - were eligible for a premium of $€ 45$ per hectare. The effect of the premium on the final is limited to $€ 0.03-0.04 / 1$ biodiesel [43].

\subsubsection{Support to biofuel production facilities}

Governmental support for the construction of a production plant can be an incentive to investors. This is particularly interesting for the production of secondgeneration biofuels. These are fuels derived from a broad range of feedstock products, including by-products and woody materials (lignocellulosic ethanol \& FischerTropsch biodiesel). The technologies to produce these advanced biofuels are generally in the developing or demonstration phase. For the more common biofuels (biodiesel \& ethanol) the impact of this kind of support is very limited. Countries as Germany, France, Austria and Sweden supported biofuel production facilities in the demonstration phase. Nowadays the support is concentrated on second-generation biofuels [43].

\subsubsection{Fuel quality standards}

Fuel quality standards are essential to create guidelines for the producer side and confidence in the product on the consumer side. Since 2004 a EU-wide biodiesel standard EN14214 has been established. At the same time the maximum biodiesel content in blends is limited to $5 \%$ volume following the CEN diesel standard EN590 [44]. The Commission called for a revision of EN590 to increase the maximum blending capacity [43].

\subsubsection{Support by tax reduction}

In 2003, the European Energy Taxation Directive was amended to allow the Member States to grant tax reductions and/or exemptions in favor of renewable fuels under certain conditions [45]. This measure is particularly effective in countries with high taxes on fossil fuels. In

Table 1. Comparison between the conventional method and the supercritical methanol method for biodiesel production [10]

\begin{tabular}{lcc}
\hline & Conventional method & scMeOH method \\
Reaction time & $1-8 \mathrm{~h}$ & $120-240$ sec. \\
Reaction conditions & $0.1 \mathrm{MPa}, 30-65^{\circ} \mathrm{C}$ & $>8.08 \mathrm{MPa},>239.5^{\circ} \mathrm{C}$ \\
Catalyst & Acid or alkali & None \\
Free fatty acids & Saponified products & Methyl esters \\
Yield & Normal & Higher \\
Products to be removed & Methanol, catalyst and saponified products & Methanol \\
Process complexity & High & Low \\
\hline
\end{tabular}


2005, different European countries granted a biodiesel tax reduction: Germany $(0.47 € / 1)$, France $(0.33 € / 1)$, Austria $(0.31 € / 1)$, Sweden $(0.395 € / 1)$, Spain $(0.30 € / 1)$, Czech $(0.329 € / 1)$, Poland $(0.29 € / 1)$ and the UK $(0.30 € / 1)$. Due to the success of biofuels this led to a considerable loss of tax revenues by the member states. That is why many countries have decided to switch to a mandatory system or a mix between both systems [43].

Another approach to make biofuels more competitive is a system of tax reduction for an, by the government, authorized quota of biofuels. In this system, which has been applied in France, Italy and Belgium, tax exemption only applies to a well-defined volume (or quota) of biofuels. In this manner the government can control the amount of biofuels on the market as well as their tax revenue loss.

\subsubsection{Mandates for fuel suppliers}

A fair part of the Member States are currently developing a mandatory system in combination with a partial or full tax exemption. The benefit of such systems is twofold: the prevention of high tax revenue losses and the creation of investment security for producers.

\section{Conclusions and future outlook}

The necessity to decontaminate polluted sites is recognised worldwide, both socially and politically, because of the increasing importance placed on environmental protection and human health. Phytoremediation could be a viable option to decontaminate heavy-metal polluted soils, particularly when the biomass produced during the phytoremediation process could be economically valorised in the form of bioenergy. The use of metalaccumulating bioenergy crops might be suitable for this purpose.

If soils, contaminated with heavy metals, are phytoremediated with oil crops (such as Brassica spcs.), biodiesel production from the resulting plant oil could be a viable option to generate bioenergy. One of the major advantages of using the non-catalyzed supercritical methanol process over the more conventional basecatalyzed process for this purpose is that downstream processing (i.e. purification of glycerol and fatty acid methyl esters) becomes much simpler and can make the production of biodiesel much more attractive. Since the excess methanol can be easily recycled, and virtually no waste products are produced, it can be regarded as a good example of green - environmental friendly - chemistry. In addition, the presence of FFAs in the crude vegetable oils is not a burden in the supercritical process. Furthermore, this technology enables to process waste oil and fat products much more efficiently than in the conventional (acid- or base-catalyzed) process because the presence of water in crude vegetable oil as well as in their wastes is not an obstacle in the supercritical process. Hence, various types of vegetable oils from virgin to crude and their wastes can be readily used for biodiesel production by the supercritical methanol method.
However, some crucial questions about the content of heavy metals in biodiesel, obtained from the oil of plants used for the fytoremediation of soils polluted with heavy metals, remain unanswered. In their study on the accumulation and distribution of heavy metals in oil crops, Angelova et al. [46] determined the content of the heavy metals $\mathrm{Cd}, \mathrm{Cu}$, and $\mathrm{Pb}$ in plant organs and in the oil of rape seed (Brassica napus L.), which was grown in a polluted area. The distribution of heavy metals in the organs of crops had a selective character that decreased in the following order: leaves $>$ stems $>$ roots $>$ fruit shell $>$ seeds. Although the concentration effect of heavy metals was the lowest in the seeds (which contain the pure plant oil), the quantities of $\mathrm{Pb}, \mathrm{Cu}$ and $\mathrm{Cd}$ in the rape seed oil were higher than the accepted maximum permissible concentrations for human consumption. If biodiesel exhaust fumes from such rape seed plants - specifically selected for their high heavy-metal uptake capacity - will have hazardous metal emissions is virtually unknown. Further scientific research to investigate this issue is essential. It is crucial that the remediation effect of the plant will not be tackled by higher heavy-metal emissions of vehicles, running on biodiesel obtained from phytoremediation plants.

\section{References}

1. RÖMKENS, P. F. A. M. et al. Risico's van cadmium en lood in moestuinen in de Kempen. Nageningen: Altera, 2005. 166 p.

2. EEA European Environment Agency, Down to earth: Soil degradation and sustainable development in Europe. Environmental Issues Series, 2000, No 16, p. 1-32.

3. EMEP Status Report 2/06, Heavy Metals: Transboundary Pollution of the Environment. Joint MSC-E \& CCC Report, 2006. $79 \mathrm{p}$.

4. WILTSE, C. C.; ROONEY, W. L.; CHEN, Z.; SCHWAB, A. P.; BANKS, M. K. Greenhouse evaluation of agronomic and crude oil phytoremediation potential among alfalfa genotypes. Journal of Environmental Quality, 1998, 27, p 169-173.

5. VAN DER LELIE, D.; SCHWITZGUÉBEL, J. P.; GLASS, D. J.; VANGRONSVELD, J.; BAKER, A. Assessing phytoremediation's progress in the United States and Europe. Environ. Sci. Technol., 2001, 35, p. 447A-452A.

6. MILLER, R. R. Phytoremediation, technology overview report. Ground-Water Remediation Technologies Analysis Center, Pitssburgh, PA, USA, 1996. 80 p.

7. MEERS, E. Phytoextraction of heavy metals from contaminated dredged sediments. Thesis submitted in the fulfilment of the requirements for the degree of Doctor (Ph.D.) in Applied Biological Sciences, Ghent University, Belgium, 2005. 341 p.

8. BAKER, A. J. M.; REEVES, R. D. \& HAJAR, A. S. M. Heavy metal accumulation and tolerance in British populations of the metallophyte Thlaspi caerulescens J. \& C. Presl. (Brassicaceae). New Phytologist, 1994, 127, p 61-68.

9. WINDSOR, J. On some species of Thlaspi. The Naturalist, 1866, 2, p 31-32.

10. BAKER, A. J. M. \& BROOKS, R. R. Terrestrial higher plants which hyperaccumulate metallic elements - a review of their distribution, ecology and phytochemistry. Biorecovery, 1989, 1, p 81-126. 
11. ROBINSON, B. H.; LEBLANC, M.; PETIT, D.; BROOKS, R. R.; KIRKMAN, J. H.; GREGG, P. E. H. The potential of Thlaspi caerulescens for phytoremediation of contaminated soils. Plant and Soil, 1998, 203, p 47-56.

12. EBBS, S. D.; KOCHIAN, L. V. Toxicity of $\mathrm{Zn}$ and $\mathrm{Cu}$ to Brassica species:implications for phytoremediation. Journal of Environmental Quality, 1997, 26, p 776-781.

13. KUMAR, P. B. A. N.; DUSHENKOV, V.; MOTTO, H.; RASKIN, I. Phytoextraction: the use of plants to remove heavy metals from soils. Environmental Science and Technology, 1995, 29, p 1232-1238.

14. SALT, D. E.; BLAYLOCK, M.; KUMAR, N. P. B. A.; DUSHENKOV, V.; ENSLEY, B. D.; CHET, I.; RASKIN, I. Phytoremediation: a novel strategy for the removal of toxic metals from the environment using plants. Biotechnology, 1995, 13, p 468-474.

15. EBBS, S. D.; LASAT, M. M.; BRADY, D. J.; CORNISH, R.; GORDON, R.; KOCHIAN, L. V. Phytoextraction of cadmium and zinc from a contaminated soil. Journal of Environmental Quality, 1997, 26, p 1424-1430.

16. LIPHADZI, M. S.; KIRKHAM, M. B. Phytoremediation of soil contaminated with heavy metals: a technology for rehabilitation of the environment. S. Afr. J. Bot., 2005, 71, p 24-37.

17. DO NASCIMENTO, C. W.; AMARASIRIWARDENA, D.; XING, B. Comparison of natural organic acids and synthetic chelates at enhancing phytoextraction of metals from a multi-metal contaminated soil. Environmental Pollution, 2006, 140, p 114-123.

18. MEERS, E.; RUTTENS, A.; HOPGOOD, M.; LESAGE, E.; TACK, F. M. G. Potential of Brassica rapa, Cannabis sativa, Helianthus annuus and Zea mays for phytoextraction of heavy metals from calcareous dredged sediment derived soils. Chemosphere, 2005, 61, p 561-572.

19. MARCHIOL, L.; ASSOLARI, S.; SACCO, P.; ZERBI, G. Phytoextraction of heavy metals by canola (Brassica napus) and radish (Raphanus sativus) grown on multicontaminated soil. Environmental Pollution, 2004, 132, p 2127.

20. GRISPEN, V. M. J.; NELISSEN, H. J. M.; VERKLEI, J. A. C. Phytoexttraction with Brassica napus: a tool for sustainable management of heavy metal contamianted soils. Environmental. Pollution, 2006, 144, p 77-83.

21. DEMIRBAS, A. Biodiesel from vegetable oils via transesterification in supercritical methanol. Energy Convers. Manage, 2002, Vol. 43, p 2349-2356.

22. MITTELBACH, M.; REMSCHMIDT, C. Biodiesel: the comprehensive handbook. Austria: M. Mittelbach, 2004. $332 \mathrm{p}$.

23. MA, F.; HANNA, M. A. Biodiesel production: a review. Bioresource Technology, 1999, Vol. 70, p 1-15.

24. PINTO, A. C.; GUARIEIRO, L. L. N.; REZENDE, M. J. C.; RIBEIRO, N. M.; TORRES, E. A.; LOPES, W. A.; PEREIRA, P. A. DE P.; DE ANDRADE, J. B. Biodiesel: an overview. J. Braz. Chem. Soc., 2005, Vol. 16, No 6B, p 1313-1330.

25. SCHUCHARD, U.; SERCHELI, R.; VARGAS, R. M. Transesterification of vegetable oils: a review. J. Braz. Chem. Soc., 1998, Vol. 9, No 1, p 199-210.

26. FRIEDMAN, B.; PRYDE, E. H.; MOUNTS, T. L. Variables affecting the yields of fatty esters from transesterified vegetable oils. JAOCS, 1984, Vol. 61, p 1638-1643.
27. MARCHETTI, J. M.; MIQUEL, V. U.; ERRAZU, A. F. Possible methods for biodiesel production. Renew. Sust. Energy Rev., 2007, Vol. 11, No. 6, p 1300-1311.

28. ISO, M.; CHEN, B.; EGUCHI, M.; KUDO, T.; SHRESTHA, S. Production of biodiesel fuel from triglycerides and alcohol using immobilized lipase. J. Mol. Catal. B - Enzym, 2001, Vol. 16, p 53-58.

29. SWAB, A. W.; BAGBY, M. O.; FREEDMAN, B. Preparation and properties of diesel fuels from vegetable oils. Fuel, 1987, Vol. 66, p 1372-1378.

30. SAKA, S.; KUSDIANA, D. Biodiesel fuel from rape seed oil as prepared in supercritical methanol. Fuel, 2001, Vol. 80, p 225-231.

31. FUKUDA, H.; KONDO, A.; NODA, H. Biodiesel fuel production by transesterification of oils. J. Biosci. Bioeng., 2001, Vol. 92, p 405-416.

32. VAN GERPEN, J. Biodiesel processing and production. Fuel Process. Technol., 2005, Vol 86, p 1097-1107.

33. KUSDIANA, D.; SAKA, S. Kinetics of transesterification in rape seed oil to biodiesel fuel as treated in supercritical methanol. Fuel, 2001, Vol. 80, p 693-698.

34. WEYTEN, H.; WILLEMS, L.; ADRIANSENS, W.; VAN GINNEKEN, L.; DEVOLDERE, K. Biodiesel fuel from vegetable oil by transesterification in supercritical methanol. In Proc. ESF Workshop Supercritical Fluids as Active Media: Fundamentals and Applications. Valladolid, 20-22 Sept. 2001. 177 p.

35. WEYTEN, H.; WILLEMS, L.; ADRIANSENS, W.; VAN GINNEKEN, L. Transesterification reaction of vegetable oil in supercritical methanol. In Proc. $8^{\text {th }}$ Meeting Supercritical Fluids. Bordeaux, 14-17 Apr. 2002, p. 139.

36. MADRAS, G.; KOLLURU, C.; KUMAR, R. Synthesis of biodiesel in supercritical fluids. Fuel, 2004, Vol. 83, p 2029-2033.

37. KUSDIANA, D.; SAKA, S. Methyl esterification of free fatty acids of rape seed oil as treated in supercritical methanol. J. Chem. Eng. Jpn., 2001, Vol. 34, p 383-387.

38. WARABI, Y.; KUSDIANA, D.; SAKA, S. Reactivity of triglycerides and fatty acids of rape seed oil in supercritical alcohols. Bioresour. Technol., 2004, Vol. 91, p 283287.

39. KUSDIANA, D.; SAKA, S. Effects of water on biodiesel fuel production by supercritical methanol treatment. Bioresour. Technol., 2004, Vol. 91, p 289-295.

40. SCHNEPF, R. European Union biofuels policy and agriculture: an overview. CRS Report for US Congress, March 2006, p 1-6.

41. Energy information administration. Available from Internet: <http://tonto.eia.doe.gov/dnav/pet/hist/brted.htm>.

42. Council Regulation (EC), No. 1251/1999, Article 6(1), May 1999.

43. PELKMANS, L. et al. Measures for the promotion of biofuels. Premia, May 2007, p 14-25.

44. Dieselnet. Available from Internet: $<$ http://www.dieselnet.com/>.

45. Council Directive 2003/96/EC. Restructuring the Community framework for the taxation of energy products and electricity.

46. ANGELOVA, V.; IVANOVA, R.; IVANOV, K. Heavy metal accumulation and distribution in oil crops. Communications in Soil Sci. Plant Analysis, 2005, Vol. 35, No. 17-18, p 2551-2566. 


\title{
FITOREMEDIACIJOS TAIKYMAS SUNKIAISIAIS METALAIS UŽTERŠTAME DIRVOŽEMYJE DERINANT SU BIOENERGIJOS GAMYBA
}

\author{
L. Van Ginneken, E. Meers, R. Guisson, A. Ruttens, K. Elst, F. M. G. Tack, J. Vangronsveld, L. Diels, W. Dejonghe
}

Santrauka

2007 m. birželị Flandrijoje (Belgija) pradètas vykdyti projektas, kuriame mes pritaikysime fitoremediaciją siekdami išvalyti sunkiuosius metalus iš dirvožemio. Sunkiụjų metalų patekimas į rapsus, kukurūzus ir kviečius bus suintensyvintas didinant šių sunkiujų metalų biopriimamumą dèl pridedamų biodegraduojančių fizikinių-cheminių priedų bei stimuliuojant mikrobiologinių bendrijų pajëgumą augale ir aplink ji sugerti sunkiuosius metalus. Be to, nuimta javų biomasẻ bus perdirbta ị bioenergiją, taikant ịvairias energijos gavybos technologijas. Energijos ir sunkiujų metalų masès balansas bus palygintas pagal keturias skirtingas energijos gavybos technologijas (anaerobinis kompostavimas, deginimas, dujofikavimas ir biodyzelio gamyba). Visa gauta informacija leis ekonominiu požiūriu ịvertinti fitoremediacijos, derinamos su bioenergijos gamyba, taikymą valant sunkiaisiais metalais nevienodai užterštus plotus. Pateikiamoje apžvalgoje pirma aptarsime svarbiausius fitoremediacijos projekto etapus. Antra, detaliau apžvelgsime literatūrą apie rapsų pajègumą išvalyti dirvožemi, užterštą sunkiaisiais metalais, ir galimybes gaminti biodyzeli iš (sunkiaisiais metalais užterštu) rapsų sèklų.

Reikšminiai žodžiai: fitoremediacija, sunkieji metalai, biomasė, energijos gamyba, rapsai, biodyzelis.

\section{ПРИМЕНЕНИЕ ФИТОРЕМЕДИАЦИИ В ПОЧВЕ, ЗАГРЯЗНЕННОЙ ТЯЖЕЛЫМИ МЕТАЛЛАМИ И ПРИСПОСАБЛИВАЕМОЙ ДЛЯ ПРОИЗВОДСТВА БИОЭНЕРГИИ}

Л. Ван Гиннекен, Э. Меерс, Р. Гуйссон, А. Руттенс, К. Элст, Ф. М. Г. Так, Я. Вангронсвелд, Л. Диелс, В. Дейонге Р е $з$ ю м е

В июне 2007 г. во Фландере (Бельгия) была начата работа над проектом по фиторемедиации с целью очищения почвы от тяжелых металлов. Процесс поглощения тяжелых металлов рапсом, кукурузой и пшеницей будет более интенсивным благодаря введению биодеградирующих физико-химических добавок и стимуляции способности микробиологических сообществ в растении и вокруг него впитывать тяжелые металлы. Снятая биомасса зерновых с помощью различных технологий по производству энергии будет конвертирована в биоэнергию. Баланс энергии и массы тяжелых металлов будет сравнен с помощью четырех разных технологий по производству энергии (анаэробического компостирования, сжигания, газофикации, производства биотоплива). Полученная информация позволит с экономической точки зрения оценить применение фиторемедиации как для очищения площадей, в разной степени загрязненных тяжелыми металлами, так и для производства биоэнергии. В статье прежде всего проанализированы важнейшие этапы проекта по фиторемедиации. Затем произведен обзор литературы о способности рапса благодаря фиторемедиации очищать почву, загрязненную тяжелыми металлами, и возможностях производства биотоплива из семян рапса, загрязненных тяжелыми металлами.

Ключевые слова: фиторемедиация, тяжелые металлы, биомасса, производство энергии, семена рапса, биотопливо.

Luc Van GINNEKEN. Dr ing, Project manager, Environmental and Process Technology Centre of Expertise, Flemish Institute for Technological Research (VITO).

Doctor of Science (Biology), University of Antwerp (Belgium), 1999. Master in Biochemical Engineering, Karel de Grote Hogeschool (Belgium), 1989. Publications: author/co-author of 2 book chapters, over 20 scientific papers, 3 patents. Research interests: process technology, supercritical fluid technology, biomass conversion, industrial biotechnology.

Ruben GUISSON. Ir, Researcher, Energy Technology Centre of Expertise, Flemish Institute for Technological Research (VITO).

Master in Engineering in Land and Forest Management, Catholic University of Leuven (Belgium), 2002. Research interests: energy technology, renewable energy sources (biomass), sustainable energy.

Kathy ELST. Dr, Researcher, Environmental and Process Technology Centre of Expertise, Flemish Institute for Technological Research (VITO).

Doctor of Science (Physics), University of Antwerp (Belgium), 1993. Master in Physics, University of Antwerp (Belgium), 1989. Publications: author/co-author of over 20 scientific papers, over 50 patents. Research interests: sustainable process technologies, supercritical fluid technology, separation technology, biofuels.

Ludo DIELS. Dr, Research Unit Manager, Environmental and Process Technology Centre of Expertise, Flemish Institute for Technological Research (VITO).

Doctor of Science (Biochemistry), University of Antwerp (Belgium), 1981. Master in Cell Biology, University of Antwerp (Belgium), 1976. Publications: author/co-author of over 250 scientific papers, 5 patents. Research interests: microbiology, environmental biotechnology, molecular biology, soil remediation, phytoremediation.

Winnie DEJONGHE. Dr ir, Project manager, Environmental and Process Technology Centre of Expertise, Flemish Institute for Technological Research (VITO).

Doctor of Applied Biological Sciences, University of Ghent (Belgium), 2003. Master in Agricultural Engineering, Free University of Brussels (Belgium), 1997. Publications: author/co-author of over 20 scientific papers. Research interests: soil, sediment and groundwater remediation, environmental biotechnology, microbial community structure, molecular techniques. 